\title{
School Choice, Exclusion, and Race Taming in Milwaukee: A Meta-ethnography
}

\author{
Andrew H. Hurie ${ }^{1} \mathbb{D}$
}

Accepted: 9 March 2021 / Published online: 24 March 2021

(C) The Author(s), under exclusive licence to Springer Nature B.V. 2021

\begin{abstract}
This article presents a meta-ethnography (Urrieta Jr and Noblit (eds), Cultural constructions of identity: meta ethnography and theory, Oxford University Press. 2018. https://doi.org/10.1093/oso/9780190676087.001.0001) of school choice across education sectors in Milwaukee, Wisconsin, USA. A site of intense contention and experimentation around school choice, Milwaukee constitutes a unique case that can offer insights into similar education reforms increasingly being implemented on a global scale. In synthesizing six book-length qualitative research studies, I engage key differences among the texts and then offer a lines-of-argument synthesis (Noblit and Hare, Meta-ethnography: synthesizing qualitative studies. Sage Publications, 1988. https://doi.org/10.4135/9781412985000) that reinterprets the studies as stories about whiteness' right to exclude across school sectors (Aggarwal, in: Fernandes (ed), Feminists rethink the neoliberal state: inequality, exclusion, and change, New York University Press, 2018. https://doi.org/10.18574/nyu/97814 79800155.003.0003; Harris, Harv Law Rev 106(8):1707-1791, 1993. https://doi. org/10.2307/1341787). Lastly, I engage various layers of interpretation in the studies (via the interconnected avenues of theory, researcher positionality, and methodology) to describe race taming discourses that attempt to make race, racism, and white supremacy manageable and containable through insufficient education interventions. I suggest that both exclusion and race taming can offer cautionary lessons about the tenuousness and possibilities of interest convergence during a time of apparently renewed cross-racial support for public education in the contemporary Milwaukee education scene.
\end{abstract}

Keywords Meta-ethnography $\cdot$ School choice $\cdot$ Desegregation · White supremacy · Milwaukee

Andrew H. Hurie

ahurie@carrollu.edu

1 Education Department, Carroll University, 100 N. East Avenue, Waukesha, WI 53186, USA 
On April 7, 2020, thousands of Milwaukee voters clad in face masks, sweatshirts, and winter coats, waited in line for hours to cast a vote in the Wisconsin general election. Despite white Republican lawmakers' blatant voter suppression and ridicule-worthy attempts to convince people of the safety of in-person voting during the onset of the COVID-19 pandemic, popular media outlets declared victory for the liberal-leaning state Supreme Court candidate (e.g. Epstein, 2020). A ballot item that received far less national media coverage was the referendum to provide $\$ 87$ million of additional funding to the city's public schools. Locally, the referendum sparked a new round of contentious debate when three prominent charter and private school leaders published an opinion column opposing the referendum (Diaz et al., 2020).

Despite such opposition, the referendum passed with widespread support across several officialized racial categories: $78 \%$ of all voters approved the measure, with approval rates of $85 \%$ in majority African American wards, $78 \%$ in majority Latino wards, and $74 \%$ in majority white wards ${ }^{1}$ (Johnson, 2020). This result appears to present a stark contrast to the overt white animus that characterized the school district's last attempted referendum in 1993, when white voters overwhelmingly rejected the requested $\$ 377$ million property tax levy (Johnson, 2020). Beyond these percentages and demographic labels, what might the results and controversy around the 2020 referendum suggest about race relations and public education at a time of 'post-colorblindness' (Leonardo, 2020)? Does the approved referendum represent a new commitment to public education, and a concomitant turn away from the city's highly visible charter and voucher reforms of the past three decades?

In this article, I present a meta-ethnography of school choice in Milwaukee as one approach to exploring the history of ideas about school choice while attending to the unique and changing context that Milwaukee offers as a case. Specifically, I explore the two-part question: How does qualitative scholarship theorize school choice in Milwaukee, and what lessons does this scholarship offer for the city's contemporary education scene? A site of intense conflict around school choice, Milwaukee offers an example of the dynamic relations between local contentious practice and enduring struggles around race and class (Holland \& Lave, 2001).

The article makes several methodological and conceptual contributions. Methodologically, I attempt to center place in this meta-ethnographical synthesis. It is one way to balance the affordances of research synthesis with the imperatives of attending to place in school choice matters (Henig, 2009), as well as social science research more broadly (Tuck \& McKenzie, 2015). I do not suggest that the findings are directly generalizable to other contexts, but rather that they may help others draw insights about different, localized struggles against enduring race- and class-based oppression (Holland \& Lave, 2001).

\footnotetext{
1 Johnson's (2020) reporting did not mention American Indian or Asian American voters. However, my review of the 2020 spring election results suggests that the MPS referendum passed in each of the wards with the five highest percentages of Native and Asian American voters, respectively (City of Milwaukee, 2019, 2020).
} 
Conceptually, my synthesis of six texts reinterprets them as stories about the shifting terrains of race- and class-based oppression in Milwaukee, and builds on the important work of Chapman and Antrop-González (2011), who use critical race theory's tenets of interest convergence, intersectionality, and the centrality of race to critique the race evasiveness of market theory in Milwaukee's choice-based education reforms. Through my engagement with various layers of interpretation in the studies, critical theories, and contemporary media sources, I argue that exclusion has constituted a fundamental mechanism of white supremacy and its structuring of school choice in Milwaukee across public and private school sectors (Aggarwal, 2018; Harris, 1993). Moreover, I suggest that the uncritical theorizing of these exclusionary practices constitutes a race taming discourse that does not avoid questions of race, racism, and white supremacy, but rather attempts to make them manageable, fixable, and containable through insufficient education interventions. Both exclusion and race taming can offer cautionary lessons about some white Milwaukeeans' ostensibly renewed support for public education and the im/possibilities of solidarity at a time of potential interest convergence. In the next section, I present background on several elements of school choice in Milwaukee.

\section{Background}

Prior to the civil rights uprisings in 1960s Milwaukee, a handful of public and private school programs were designed to prepare students for higher education, while many others focused on training students to work in the city's factories, tanneries, and breweries (Miner, 2013). During this period, schooling was primarily organized by neighborhood, even though the Milwaukee Public Schools (MPS) had allowed some students to attend schools outside of their neighborhoods since the 1930s (Chapman \& Antrop-González, 2011). To be sure, public schooling in the city was also predicated on Indigenous erasure, anti-Blackness, and the 'Americanization' of European immigrants not considered white (Dougherty, 2004; Tyack, 1974).

Compared to U.S. Midwestern cities like Chicago and Detroit, Milwaukee's Black population remained relatively small until the 'Late Great Migration' of Black people from southern U.S. states during the 1940s (Dougherty, 2004). These demographic shifts coincided with changes in the city's racist structuring of schools, jobs, and housing (Trotter, 2007). Tellingly, an NAACP survey conducted in 1960 found that schools in Milwaukee's "central city were 90 percent black" (Wisconsin Historical Society, 2020). In other words, the school district's educational policies and practices constituted elements of the city's de facto racial segregation, the flipside of white middle-class suburbanization during the mid-twentieth century (Margonis \& Parker, 1995). In response to restrictive racial covenants, redlining, and 'urban renewal' through Indigenous, Black, and Latinx displacement, many African American collectives and their allies developed 
thriving cultural institutions and waged sophisticated campaigns for open housing and desegregated schools (Jones, 2009; Metcalfe, 2014).

\section{School Desegregation}

In 1964, a collective of African American activists including attorney Lloyd Barbee, began organizing public school boycotts, Freedom Schools, and human chain-ins to protest the discriminatory policies and practices of MPS (Dougherty, 2004). One year later, Barbee filed a lawsuit alleging intentional segregation in the public schools. After a drawn-out litigation process, the white federal judge John Reynolds ruled in favor of the plaintiffs in 1976, and the parties reached an out-of-court agreement three years later (Dougherty, 2004).

\section{Chapter 220}

Stemming from Judge Reynolds' ruling, school integration aid, commonly referred to as the Chapter 220 program, was established in 1976. It was a voluntary intra- and inter-district transfer program, which purportedly sought to use state funds to achieve 'racial balance' (Kava \& Pugh, 2017). A handful of U.S. metropolitan areas implemented similar inter-district student transfer programs in response to community uprisings against the entrenched racial segregation in their public school systems (Holme \& Finnigan, 2018).

\section{The Milwaukee Parental Choice Program}

Partly in response to enduring educational inequalities, the Milwaukee Parental Choice Program (MPCP) began in 1990, and is now the US' oldest urban school voucher program (Witte et al., 2014). Early support for school vouchers was rife with ideological diversity, such that groups of Black nationalists and white conservative philanthropists worked with Black and white politicians to pass the MPCP into law (Carl, 1996). It began as a targeted program that provided a small number of school vouchers to low-income families living in the city. Since its inception, the MPCP has expanded significantly, serving as the precedent for additional voucher programs, including one in Racine, WI, and another whose scope is statewide (Pugh, 2017).

\section{Charter Schools}

The first charter school legislation in Wisconsin was enacted in 1993, and charter schools have expanded precipitously since then, especially in Milwaukee where three governing bodies beyond the public school district can authorize charter 
schools (Kava \& Pugh, 2017, 2017). African American community activist and former MPS Superintendent Howard Fuller was a key advocate in the expansion of charter schools throughout the city and state (Pedroni, 2007), although charter school support has included people with a variety of political motivations (Dahlk, 2010).

\section{Open Enrollment}

Launched in 1998, open enrollment is a statewide program that allows students to attend schools outside their school district of residence if parents comply with certain application requirements and the receiving district has space for the student (Kava, 2017). This ostensibly race-neutral program has replaced the race-based Chapter 220 program (Kava, 2017).

\section{Educational Philanthropy}

Several of the above education reforms have been financed by conservative foundations and white venture philanthropists, including the Bradley Foundation, Bill Gates, and Betsy DeVos, although some African American and Latinx collectives have been central advocates and users of school choice options (Beck, 2017; Chapman \& Antrop-González, 2011).

Whether inter- and intra-district open enrollment, school vouchers, or charter schools, Milwaukee is a city with long-standing engagements around what have become known as 'school choice' policies. The city thus represents an important and unique case to examine the confluence of diverse school choice policies, cognates of which have been taken up on a global scale (Carnoy, 2017; Verger et al., 2016). In the following section, I outline several key theoretical constructs that have guided this meta-ethnography.

\section{Conceptual Framework}

That market-based education reforms have deeply affected schooling in Milwaukee is undeniable. Yet the meanings associated with those market-based reforms remain under contentious debate, and relevant scholarship is replete with diverging appraisals of choice policies' effects on student outcomes, their potential selective practices, and their underlying political implications (e.g. Farrell \& Matthews, 2006; Witte, 2000; Wolf, 2012). In this article, I draw on the critical race tenet of interest convergence (Bell, 1980) and analyses of the exclusionary forces inherent in racial capitalism (Robinson, 2000). Interest convergence is a helpful lens to make sense of voters' recent support for public education, while racial capitalism offers an explanatory framework for the racial logics undergirding the various exclusionary practices recounted in the texts. In this section, I also discuss several key aspects of 
meta-ethnography (Noblit \& Hare, 1988; Urrieta \& Noblit, 2018), which I understand as a research approach with potential to shed light on the local contexts in which enduring struggles around race and class take shape (Holland \& Lave, 2001).

\section{Interest Convergence}

Interest convergence holds that changes to societal inequalities often take place when dominative and minoritized groups coincide, albeit temporarily, on specific issues and demands. According to Derrick Bell's (1980) often-cited explanation:

The interest of blacks in achieving racial equality will be accommodated only when it converges with the interests of whites... Racial justice-or its appearance-may, from time to time, be counted among the interests deemed important by the courts and by society's policymakers (p. 523).

Bell's (1980) words highlight the precariousness of converging interests. While critical race scholars have often framed interest convergence within a loss-gain binary that demands that whites give up material resources and/or social standing (Milner, 2008), Chapman and Antrop-González (2011) highlight a different kind of loss: "Interest convergence allows minority groups to gain greater access to social equity, but often by sacrificing something yet unknown and unforeseen" (p. 791; see also Irvine \& Irvine, 2007). Their study of school choice in Milwaukee denounces policymakers' attempts to promote market-based reforms while evading race, an approach that undermined earlier interests shared among differentially-positioned politicians and progressive African American leaders in Milwaukee (Chapman \& Antrop-González, 2011).

Interest convergence has been an important tool to conceptualize and potentially transform the racist structures of schooling in the US (Milner, 2008). The construct is closely connected to the broader tradition of critical race theory (CRT), which has led to important analyses of the racialized dimensions of class. At the same time, various iterations of CRT use race to think through class without analyzing the fundamental compositions and conditions of possibility for each social phenomenon (Leonardo, 2013). Thus, I turn to theories of racial capitalism that consider these phenomena as a dialectical unity (Brown \& De Lissovoy, 2011).

\section{Racial Capitalist Exclusion}

The possibilities and enclosures of capitalism initially took shape through Europeans' racialist epistemologies and exploitation of labor, thereby situating race and racialization at the core of all subsequent iterations of capitalism (Robinson, 2000). In other words, capitalism and white supremacy sustain each other, such that "capitalism is racial capitalism" (Melamed, 2015, p. 77, italics in original). Within racial capitalism as a global project, whiteness becomes a form of property sustained through violent exclusion. As Cheryl Harris (1993) asserts, the protection of whiteness, both materially and ideologically, is founded on the right to exclude: "[J]ust as whiteness as property embraced the right to exclude, whiteness as a theoretical 
construct evolved for the very purpose of racial exclusion. Thus, the concept of whiteness is built on both exclusion and racial subjugation" (p. 1737). Through de jure and de facto segregation, both in and outside of schools, white America has sought to exploit, exclude, and contain people of color.

In education, white supremacist-structured choosing and exclusion did not begin with school privatization in the form of private school vouchers and charter schools. Aggarwal's (2018) "genealogy of choice" makes this point convincingly:

[T] he structuring of universal rights as individual private choices ensured the market's embeddedness into the public and required the cultivation of a consumer-oriented citizenship predicated on exclusion, making it so that the commons - represented by public education in this case-was always already characterized by the production of social separateness that is integral to racial capitalism (pp. 79-80).

Whiteness' hierarchical partitioning of people and concomitant exploitation of labor is thus predicated on a right to exclude, yet appearances of inclusion also operate in the form of interest convergence. Importantly, these processes take shape and are resisted through local struggles, and thus I draw from a research methodology that pays particular attention to context.

\section{Meta-ethnography}

As an approach to qualitative research synthesis, meta-ethnography strives to translate whole qualitative studies (or more specifically, their 'storylines') into one another (Noblit \& Hare, 1988; Urrieta \& Noblit, 2018). Unlike other forms of research synthesis, it does not attempt to distill general findings across cases. As Noblit (2018) explains: "In the place of generalization, meta-ethnography seeks a specification of what the studies as a whole are about and then goes deeper into the meanings evident in this specified realm" (italics in original, p. 36). This process of interpretation across studies moves toward a reconceptualization of the collection (Doyle, 2003). By engaging rather than avoiding the multiple layers of interpretation inherent in qualitative research synthesis (via the interconnected avenues of theory, researcher positionality, and methodology), meta-ethnography offers the potential for theoretical innovation (Urrieta \& Noblit, 2018). As a way to make explicit and invite readers to participate in the multiple layers of interpretation in this analysis, I describe some of my relations to the work.

\section{Positionality}

I write this meta-ethnography as a white male guest/settler and member of a bilingual and multiracial middle-class family living in Milwaukee. My research and writing are also informed by the nine years I spent working at one of the only bilingual charter schools in Milwaukee, as a teacher assistant, bilingual teacher, and school administrator. Through these experiences, I became increasingly familiar with the 
complex educational landscape in the city and its many contradictions. To reconcile my work at the charter school with the broader critiques of school privatization that I encountered, I drew on progressive explanations of charter schools and their calls for cross-sector collaboration. In practice, this usually meant that I sought out learning opportunities for myself and other charter colleagues through MPS instead of MPS teachers seeking out our knowledge and 'innovations' at the charter school. Through these exchanges, I started to realize the fallacy of totalizing narratives of urban public school failure. These experiences compelled me to seek nuanced accounts of the different school sectors while also recognizing that anti-Blackness can operate even in educational interventions (like bilingual education) that originally sought to challenge white supremacy (Sung, 2018).

\section{Methods}

I began this inquiry with an interest in theorizing around school choice in Milwaukee and how it has changed since the beginning of private school vouchers in the city. Thus, I did not include texts focusing on school choice in other places or on histories of education in Milwaukee that did not delve into school choice. I entered combinations of the following terms in various search engines: Milwaukee, Wisconsin, school choice, voucher schools, charter schools, and privatization. While certain research articles analyzed particular aspects of school choice, not surprisingly, I found the book-length accounts to be much more comprehensive in their treatment of the historical context. For that reason, I decided to include only book-length qualitative studies focusing on school choice in Milwaukee while opening my inquiry to books that may not be considered 'academic' (i.e. they were not explicit in their research methodology or theoretical assumptions). This approach seemed to be more inclusive of the ways that scholars have shaped discourses around school choice in Milwaukee.

While reading the books yielded by my initial search, I sought out promising texts cited in their bibliographies and used the above criteria to determine their value to this meta-ethnography. Although Dougherty's (2004) book was widely cited and offers a rich discussion of African American-led movements to influence education in Milwaukee, it only briefly discusses voucher and charter reforms. Thus, I did not include it in this study. My search also yielded several other books with relatively brief historical accounts of school choice in Milwaukee (i.e. Carnoy et al., 2007; Ford, 2017; Van Dunk \& Dickman, 2003; Witte, 2000). However, they foregrounded quantitative comparisons across school sectors and so I did not include them.

The process of text selection took form throughout the inquiry (Urrieta \& Noblit, 2018) and represents an exhaustive synthesis of book-length qualitative studies explicating school choice in Milwaukee. It also represents my attempt to balance the tensions between specification and synthesis in a place-based inquiry. Nevertheless, my approach has excluded several valuable research articles from the primary synthesis. In discussing the selected works, I reference these articles as a way to partially compensate for this limitation. 


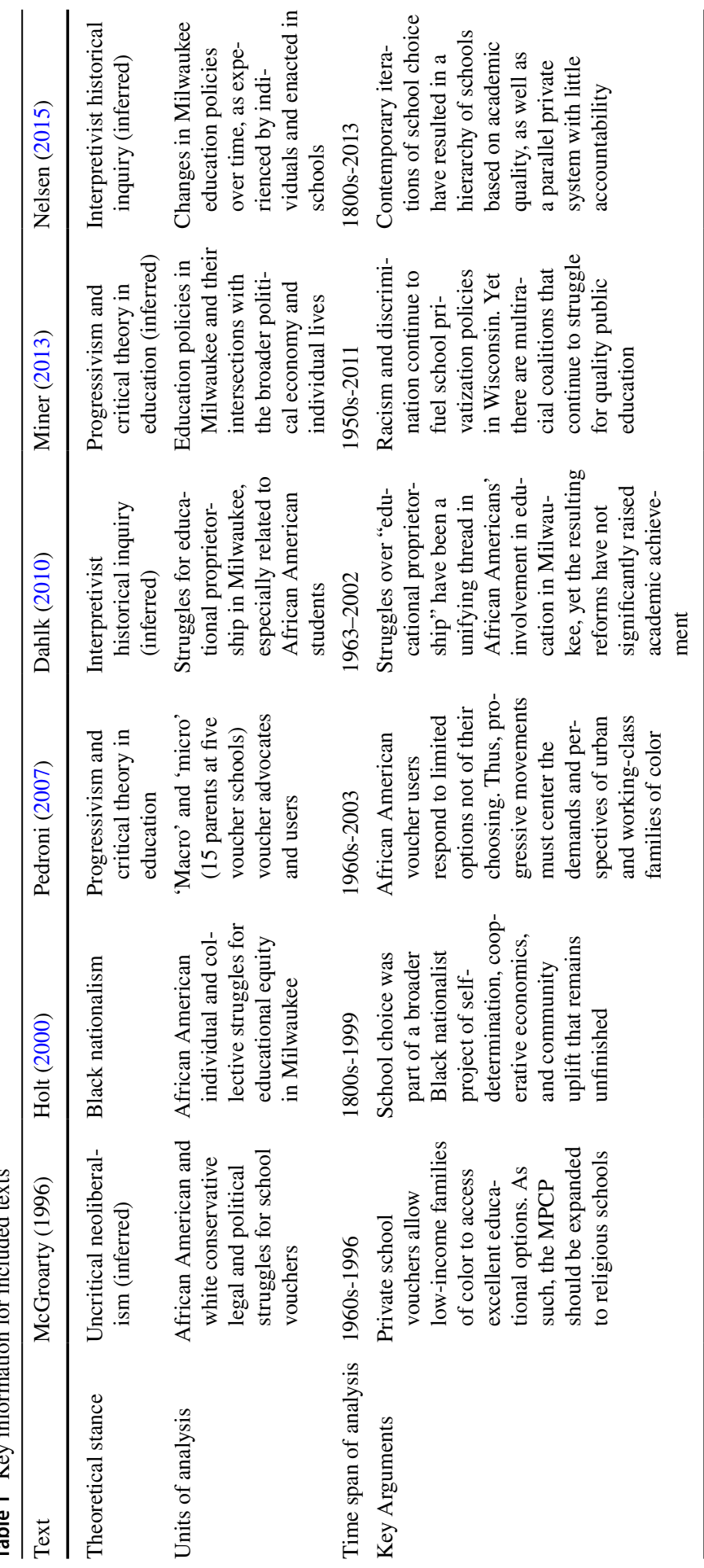


My purposive sampling includes six works totaling over 1700 pages, varying in their theoretical underpinnings and analytical foci. Table 1 summarizes key information for each text. I suggest that the six books' different theoretical orientations, publication dates, and time spans under analysis, offer the possibility of a rich and dynamic synthesis centered on Milwaukee.

Moving from text selection to inscription, I thoroughly read each text and then identified central and peripheral ideas in the storylines. I included key descriptors and ideas in a codebook, and then drafted translations of the texts, attempting to conserve the language and context of the original studies (Doyle, 2003). I also attempted to include phrases that appeared repeatedly in the original texts to ensure their prominence in my translations. This process resembled a constructivist approach to grounded theory (Charmaz, 2006).

Many of the ideas in the codebook highlighted the fluid and conflictual nature of education policy, and so I found that themes were not the most helpful conceptual unit for the study. Thus, I draw on Urrieta and Noblit's (2018) explanation of mechanisms to inform my approach of linking historical accounts of school choice with the contemporary education "scene": "Themes can be all too static, but processes are more diachronic. A subtle shift from process to mechanism could be productive as well. Focusing on the mechanisms that link elements of a scene in the unfolding of the future elements allows us to see how something becomes something else" (p. 264). An analytical focus on elements, scenes, and mechanisms enriches the historical context of this meta-ethnography, and helps to represent the mobility of place (Tuck \& McKenzie, 2015).

Synthesis of the texts involved three phases. The first overlapped with my translation of the individual texts and entailed the identification of broad time periods or scenes. I then created a version of a time-ordered matrix (Miles et al., 2014) to compare and contrast the key elements that each text used to discuss a particular scene. Due to space limitations, I focus on the second and third phases in this article and present Table 2 in the Appendix as an initial synthesis of key elements of school choice in Milwaukee across three scenes: de facto segregation, desegregation, and marketization. The second phase, presented in the following section, sought to identify broader differences and disagreements across the scenes. In the third phase, I drew specifically on the lenses of racial capitalism and interest convergence to attend to deeper meanings in the collection of texts and mechanisms that could help explain changes in education policy over time. These theoretical constructs also supported my consideration of the study's potential lessons for the contemporary education scene.

\section{Synthesizing Differences Across the Texts}

By interpreting across the translations of individual studies, meta-ethnography seeks to achieve a holistic view of the collection, which only becomes apparent through the research process. Noblit and Hare (1988) describe three possible relationships among studies: (1) reciprocal translations occur when studies say similar things and are in accordance; (2) refutational translations occur when studies contradict each 
other or present conflicting storylines; and (3) lines-of-argument translations are appropriate when studies are about slightly different things but collectively suggest a new perspective or interpretive context.

While reading each of the texts, I found many points of direct disagreement, and so I initially sought to write a refutational synthesis. At first, the differences seemed to coincide with the authors' stated opinions on school vouchers. However, additional differences emerged around the authors' descriptions of quality education. For example, in his defense of school choice, Holt (2000) cited some standardized test results but he relied far more on grade point averages to make his argument; he also emphasized the importance of African-centered curricula to challenge the standardized teachings of "Eurocentric culture" (p. 217). Similarly, Miner (2013), who opposed school vouchers, did not focus on comparisons of academic achievement between school sectors. Instead she emphasized innovative multicultural curricula in MPS that both preceded and continued despite the MPCP, as well as the implications of using public monies to subsidize private religious schooling.

On the other hand, McGroarty (1996) and Dahlk (2010) supported multicultural curricula relevant for students of color in Milwaukee, while simultaneously discussing standardized assessment results as the ultimate indicator of quality education. For example, although Dahlk (2010) noted the positive gains in 'educational proprietorship' forged through African American activism in Milwaukee, he declared that: "singularly and collectively these reforms have not resulted in significantly raising the academic performance of the majority of black children, especially the children of low-income families" (p. 645). Academic performance as normatively understood thus constituted the ultimate goal.

Another set of salient differences included the authors' research methodologies and analytical foci. All of the authors conducted interviews and archival research, yet they seemed to draw from three distinct scholarly traditions while utilizing these methods. Interpretive historical analysis undergirded Dahlk (2010) and Nelsen (2015). Dahlk's (2010) book contained a plethora of information, which was not surprising because it was nearly 400 pages longer than the next-longest text. The field of investigative journalism informed three of the texts (Holt, 2000; McGroarty, 1996; Miner, 2013). Miner (2013) and Holt (2000) offered more personal accounts, weaving their own experiences as community activists with other data sources. In contrast, McGroarty (1996) primarily narrated other people's experiences, implicitly leaving himself out of the telling. Pedroni (2007) followed social science conventions. For example, he offered a detailed description of his research methodology, which included semi-structured interviews and observations in various MPCP schools and school voucher-focused symposia.

In terms of their analytical scope, the earliest texts focused mostly on the MPCP, while later texts discussed more education reforms. This pattern suggests that the proliferation of choice policies across school sectors has encouraged authors to analyze them in concert, rather than discuss single programs in isolation. Moreover, two texts (Dahlk, 2010; Miner, 2013) consistently engaged events seemingly outside the field of education, including broader political economic trends like deindustrialization and suburbanization that affected the education policies and lived experiences of students, families, and educators in metropolitan Milwaukee. 
In sum, the complexity of the six texts goes well beyond a disagreement over the MPCP. Both voucher proponents (like Holt) and opponents (like Miner and Pedroni) saw the issue as a fundamental struggle for human rights and social justice, while Nelsen and McGroarty largely framed school choice as a question of academic achievement. Indeed, the authors made sense of school choice in Milwaukee through differing theoretical lenses, yet the storylines they presented all grapple (albeit in far different ways) with the legacy of racism that continues to shape the city's educational landscape. Thus, I will now offer a synthesis of the studies and their suggested actions by framing them in terms of white supremacy and school choice.

\section{White Supremacy and School Choice in Milwaukee: A Lines-of-Argument Synthesis}

In this section, I reconceptualize the studies following particular lines of argument. As Noblit and Hare (1988) explain: "[T]he translation of cases into one another sets the stage for a second-level inference about the relationship between the studies" (p. 64). A new interpretive context emerges from these studies when we consider that each of the texts discussed in different ways the entrenched racism endemic to Milwaukee.

In explicating the history of school choice in Milwaukee, it was important for each author to situate the struggle in earlier efforts to desegregate Milwaukee's public schools. In so contextualizing their studies, the authors pointed to the long history of white supremacy (though they did not all refer to it as such) that fueled official policies and practices of school segregation, desegregation, and choice. Drawing from Cheryl Harris' (1993) theorization of whiteness as property, Aggarwal (2018) argues that the coupling of individual choice with whiteness' right to exclude has constituted the dominant means of reproducing educational inequalities after the U.S. Supreme Court's apparent conferral of universal rights in Brown v. Board. It is a helpful frame to reconceptualize the six studies.

Aggarwal (2018) discusses specific school choice policies, from segregation academies in the U.S. South and magnet schools in Boston, to the MPCP and No Child Left Behind, as key cases illustrating the function of coupling individual private rights with the right to exclude, or what she terms the "twinned character of choice" (p. 86). Building from Aggarwal's (2018) work, I examine the interplay of school choice across public and private sectors in the collection of studies. It is not that this new framing erases the above differences among the books, but rather I suggest that it can help make sense of those differences while offering a portrait of Milwaukee as a place riddled with contradictions. The authors' perspectives on school choice and their proposals for action are interconnected with their theoretical lenses; considering each allows for an exploration of deeper meanings in the collection (Urrieta \& Noblit, 2018). 


\section{Magnet Schools and One-Way Busing: Attracting Whites through Black Exclusion}

The four texts (Dahlk, 2010; Holt, 2000; Miner, 2013; Nelsen, 2015) that expounded upon the implementation of school desegregation in Milwaukee all detailed how the plan was crafted to cater to white interests and avert white racial violence. Nelsen (2015) suggested that school desegregation was undergirded by an official desire to avoid "white backlash" (p. 39); thus, magnet schools and one-way busing were designed to "make integration palatable" to white families (p. 52). Similarly, Miner (2013) maintained that Superintendent McMurrin's "rhetoric of choice" was intended to "win over whites" (p. 83). Holt (2000) argued that the magnet plan provided "optimal opportunities for white families" (p. 105). It allowed whites to "opt in' to newly created specialty schools in predominantly African American neighborhoods, a practice that excluded from these better-resourced schools many neighborhood African American children (Dahlk, 2010; Holt, 2000; Nelsen, 2015; Pedroni, 2007). Additionally, one-way busing of African American students allowed white families to remain in predominantly white neighborhood schools (Dahlk, 2010; Holt, 2000; Miner, 2013; Nelsen, 2015; Pedroni, 2007).

Contrary to the rhetoric of choice, this catering to middle-class white families through choice-based magnet schools did not lessen inequalities within the public system. Both Holt (2000) and Miner (2013) used the phrase 'two-tier system' to describe the results of school desegregation. While Holt (2000) argued that desegregation increased white students' access to the best schools, Miner (2013) and Dahlk (2010) contended that school desegregation's separation between specialty and traditional schools developed more along class lines. Both lenses are important, and invite a racial capitalist critique that understands race and class as mutually constitutive forces (Brown \& De Lissovoy, 2011). The two prongs of school desegregation in Milwaukee-magnet schools and one-way busing —-maintained whiteness' exclusion and racial subjugation (Harris, 1993). White interests were the priority, the fundamental logic sustaining the plan; one-way busing allowed whites to remain in their racially concentrated neighborhood schools, thus fortifying the exclusion that allowed for the formation of those predominantly white enclaves in the first place.

\section{The MPCP: A Vehicle for Self-Determination or Exclusion?}

At first examination, the right to exclude does not seem to explain self-described conservative whites' alliances with some Black nationalists, whose demands for community control rebuked integration as a "cure-all" (Holt, 2000, p. 14). These Black nationalist groups were not trying to integrate into whiteness; rather they sought to control neighborhood institutions, both public and private (Dahlk, 2010; Holt, 2000).

This demand and underlying principle of community control somewhat overlaps with stereotypical white conservative calls for local control and small government. Because Brown v. Board failed to mandate a redistribution of resources, opting instead for a narrow focus on school desegregation (Aggarwal, 2016; Harris, 1993), 
the MPCP could be seen as a corrective to shift resource allocation to local communities, especially to those who have been historically excluded from the process. Indeed, Holt's (2000) book was structured around the premise that school choice is the new phase of the Civil Rights movement, given the 'failure' of school desegregation. Thus, for some prominent African American activists and voucher users, the MPCP constituted a step toward the redistribution of resources and direct community control (Holt, 2000; Pedroni, 2007).

At the same time, Holt (2000) credited the white attorney Clint Bolick with first articulating the legal argument for school vouchers based on civil rights case law: "we felt that [Bolick's] strategy of using civil rights laws as a foundation for our case was both shrewd and practical" (p. 94). Bolick's positions against affirmative action (Miner, 2013) and for school vouchers raise profound questions about his use of civil rights law, especially given the general support of affirmative action expressed in Holt's book. This tension is indicative of the "tenuous agreements" (Holt, 2000, p. 126) that characterized the movement, and hints at the different long-term agendas that would come to splinter the original alliances. Writing after various changes toward the universalization of the MPCP, Pedroni (2007) suggested that most "Milwaukee Black leaders" opposed voucher expansion after 1995 (p. 61). This shift warrants further attention.

Revisiting some of Holt's (2000) arguments in conjunction with more recent policy changes can help explain the shift in support. As Pedroni (2007) noted at the time of his writing, all legislative changes to the MPCP had expanded the program in terms of student enrollment and financial eligibility. Subsequent modifications of the MPCP have continued toward its universalization, by removing restrictions on enrollment and geography, and by raising family income limits (Pugh, 2017). Opposed by many original supporters of the MPCP, these changes do not merely reflect the program's greater inclusion of already privileged children.

Harambee Community School and Urban Day, two predominantly African American independent schools that Holt (2000) and McGroarty (1996) heralded as exemplars of the potential for school choice to empower African American families, have both closed within the past decade (Johnson, 2016; Richards, 2011). Although the causes of these closures are complex, including dropping enrollments, financial troubles, and managerial problems, they are partly due to the increasing accountability and accreditation requirements passed in $2009^{2}$ (Johnson, 2016; Richards, 2010). Nearly all of the MPCP pre-accreditation and accreditation agencies are predominantly white institutions, and the overwhelming majority are headquartered outside of Milwaukee. The MPCP accreditation requirements thus signal a distancing from the original program's purported support of community control.

\footnotetext{
${ }^{2}$ Urban Day left the MPCP in 2010, but continued operating under a charter from the University of Wisconsin-Milwaukee until 2016. Pressures on the school stemmed from a lost contract as well as from struggles to meet the accountability terms of the charter (Johnson, 2016). Here, I am not defending mediocre academic programs for students of color; rather, I intend to underscore that the dominant methods of gauging academic achievement need to be questioned for their complicity in whiteness, and their related logics of sorting, silencing, and excluding.
} 
Throughout the MPCP's years of operation, it has increasingly been structured by accountability mandates similar to those that govern public schools (Ford, 2017). These changes, perhaps necessary in some cases, have also constituted a shift away from community-based decision-making. Discussing the deep challenges of education in Milwaukee, State Rep. Polly Williams denounced the fundamental problem of white supremacist decision-making: "As long as you have white people with power making decisions about people of color, it is never going to work the way it should" (as quoted in Miner, 2013, p. 206). While self-described conservative whites relied on the conditional alliances with some African American collectives to pass Wisconsin's original voucher laws, it seems that whiteness' right to exclude from decision-making has rendered it less likely for the MPCP to support community control, and especially Black community control.

\section{Multiple-Choice Public Exclusion}

Following the MPCP, choice-based policies have proliferated in Milwaukee and throughout Wisconsin. Since its inception in 1998, the open enrollment program has grown steadily; it has overtaken and replaced the race-based Chapter 220 program to become the largest educational option for City of Milwaukee students outside of MPS and the MPCP (Kava, 2017). The two authors (Miner, 2013; Nelsen, 2015) who discussed the program suggested that it had resulted in further inequities. Miner argued that, as an "allegedly color-blind" program, open enrollment "eased the way for whites to transfer to predominantly white schools" (p. 226). Unlike the race-based Chapter 220 program, it did not cover transportation costs; at the same time, it provided financial incentives for suburban districts to accept open enrollment students over Chapter 220 students. Thus, in 2010, 61\% of Milwaukee students who participated in the program were white, while only $15 \%$ of MPS students identified as such (Miner, 2013). Nelsen likened the exclusionary protections granted to suburban schools via open enrollment to those granted to voucher schools in the MPCP. In open enrollment, suburban schools were not required to accept students labeled with special needs if they posed an "undue financial burden" (p. 157). Thus, suburban districts benefited financially if they accepted open enrollment students, while they maintained the right to exclude if they claimed that their finances would be adversely affected.

Choice-based policies did not only occur outside MPS after school desegregation. As Miner (2013) contended, MPS "policy makers adopted initiatives for the public schools that mimicked rather than challenged free-market policies and diminished educational options for low-income students and students of color" (p. 216). Nelsen (2015) described MPS' Neighborhood Schools Initiative (NSI) and small high schools program as two policy changes responding to the "significant competition" (p. 158) posed by charter schools, voucher programs, and open enrollment. Because of minimal changes to the city's residential racial segregation, the NSI represented an official condoning of racially segregated neighborhood schools. Miner (2013) argued that the program was a "rationalization for resegregating the schools" (p. 219), with the intent to curb white flight to the suburbs and shed the hassles 
of desegregation. Nelsen (2015) explained that the NSI was funded through cuts to busing, and the Gates Foundation grant monies failed to cover the escalating costs of small schools. Taken together, these choice-based reforms further insulated predominantly white neighborhoods and upheld whiteness' right to exclude, while further legitimizing elite white venture philanthropy as a primary impetus of education policy.

Across public and private sectors in Milwaukee, choice as education policy has been geared towards the protection of white choosing. Throughout the 1970s and 80s, MPS' 'voluntary' school desegregation plan included magnet schools and oneway busing of African American students. In the 1990s, the MPCP responded to the discontent of various African American collectives and promised a means of securing greater community control. However, with the MPCP's maturation, the decision-making processes have shifted away from communities of color while the program increasingly includes more privileged students, and spawns policy cognates statewide. Subsequent public sector choice-based policies have only deepened educational inequities. They fortify the means through which white families access predominantly white schools and limit the options of low-income families of color.

Drawing from Aggarwal's (2018) genealogy of choice and Harris' (1993) whiteness as property for my integrating scheme (Noblit \& Hare, 1988), I have argued that the six texts help to clarify the ways that choice-based policies across school sectors have catered to white interests and reinforced whiteness' right to exclude. Importantly, this new interpretive context is not meant to minimize the differences among the studies. It does, however, point to a common criticism leveraged by both opponents and proponents of school vouchers. Voucher proponents argued that the 'failure' of desegregation made it necessary to work outside the system, and voucher opponents argued that private schools served as an impetus for resegregation. Processes of exclusion underlie both critiques. In the next section, I discuss the aforementioned differences in relation to the (at times implicit) theories and policy proposals in each text.

\section{Synthesizing Theoretical Perspectives and Proposals for Action}

Beyond the authors' explanations of school choice, I find it useful to consider their theoretical perspectives and suggested political actions. My engagement with these additional layers of interpretation is not meant simply as a criticism of an individual author's writing or career trajectory. Rather, engaging these layers of interpretation can help research synthesis move toward theoretical innovation (Urrieta \& Noblit, 2018). In this place-centered meta-ethnography, I suggest that consideration of the authors' theoretical perspectives can better represent Milwaukee as a place of multiple voices. Moreover, this approach can offer lessons about the precariousness of interest convergence. To this end, I differentiate between some authors' critical theorizing of race and others' race taming discourses.

In my reading, three of the authors (Holt, 2000; Miner, 2013; Pedroni, 2007) wrote from explicitly critical perspectives, which seek to demystify the workings of power while contributing to the transformation of oppressive conditions (Freire, 
1971; Urrieta \& Noblit, 2018). Importantly, these authors did not agree on strategic matters, such as the use of school vouchers. Related disagreements also extended to their interpretations of prior education reforms during school desegregation. Such disagreements echo long-running debates among Black activists in Milwaukee about working with white people and towards racial integration, or advocating for homogenous Black institutions and community control (Dougherty, 2004).

At the same time, the three authors' appraisals of the underlying role of racism in Milwaukee's education system were quite similar. Each author critiqued traditional, whitestream unionism as a barrier to more equitable public schooling. Both Holt and Miner, perhaps the two authors who most overtly diverged, advocated multicultural curricula and emphasized the importance of teachers of color. Their respective calls for community control and democratic education are not necessarily at odds, especially in a school district in which the vast majority of students are students of color. I will explore some of the implications of a critical cross-racial project for educational justice in the conclusion.

In contrast to the first three authors, I do not consider McGroarty (1996), Dahlk (2010), or Nelsen (2015) to have theorized from a critical perspective, although their texts recounted many episodes of overt discrimination, white racial hatred, and systemic injustice. McGroarty (1996) offered particularly stark criticism of racial discrimination in urban and suburban public schools, although he dedicated comparably scant attention to the historical contexts of this discrimination or its multiple facets including housing and employment. Indeed, McGroarty (1996) discussed education largely in isolation, often framing it as the sole means of community uplift. His overt and unflinching embrace of educational marketization, however, hinted at his broader participation in neoliberalism as a global political-economic program. In this regard, McGroarty's career trajectory is important to consider.

A former speechwriter for U.S. President George H. W. Bush, McGroarty is now an adjunct professor of political management, a senior consultant for a "multinational metals and mining company," and a senior advisor for a "global agri-business" (Carmot Strategic Group, 2019). As a full participant in contemporary economies of dispossession (Byrd et al., 2018), McGroarty has clearly moved on from his advocacy of school vouchers in Milwaukee. Not only does his career point to the "tenuous agreements" (Holt, 2000, p. 126) in Milwaukee voucher politics, it also suggests that racial analysis must consider areas beyond education, and especially the global scope of white supremacy that sustains colonial-like relations in the present.

In my reading, both Dahlk (2010) and Nelsen (2015) adhered to different variations of an interpretivist paradigm seeking "culturally derived and historically situated interpretations of the social life-world" (Crotty, 2012, p. 67). In particular, Dahlk's (2010) book drew from a wide variety of sources and perspectives, thereby embracing complexity in the narration of historical events. At the same time, I would argue that his policy recommendations do not adequately wrestle with questions of power in addressing educational inequalities. For example, Dahlk (2010) suggested that successful schools institutionalized "an equation" that included "greater school autonomy and educator accountability" (p. 626) as well as the engagement of students and parents. To encourage the latter, he proposed an experimental program to "reward the parental figures" (p. 646, italics in original) for children's academic 
growth and achievement. The rewards could be in the form of government vouchers for mortgage payments, rent credits, or college savings funds. This policy recommendation does not seem to consider the broader histories and current systems of dispossession that undergird differences in academic achievement (Ladson-Billings, 2006) or the possibility of schools as (always contested) sites of social reproduction. Instead, schools maintain an unproblematic role in workforce preparation.

Moreover, Dahlk (2010) seemed to advocate for no-excuses charter schools as exemplars of quality education: "A key to raising achievement requires better classroom teachers, more skilled school leaders, and more demanding and supportive parents. These should be the first priority. The best public and private schools (many KIPP charter schools, for example) demonstrate this" (p. 645). In his conceptualization of systems of schools, the author seemed to embrace competition as the means, and raising normative notions of academic achievement as the ultimate goal, of schooling in the US. In addition, his suggestion that KIPP schools constituted ideal models of parental involvement and school culture failed to consider the exclusionary protections, racialized paternalism and militaristic discipline that have been documented in these and similar no-excuses schools (e.g. Golann \& Torres, 2018; Lack, 2011). In fact, corporatized no-excuses charter schools would seem almost antithetical to the place-based, democratic education that Dahlk (2010) promoted in other sections of the text.

Similarly, Nelsen's (2015) interpretivist approach to historical inquiry would benefit from a deeper consideration of issues of race and power. The author's three erasof no choice, forced choice, and school choice — could be understood as a typology of Milwaukee education history from an African American perspective. Still, the typology does not include an explicit critique of whiteness, which would certainly alter its phrasing. Contrary to 'no choice,' whites fiercely protected their overwhelming choice to attend racially concentrated schools, while the school board operated to maximize educational quality for them (Pedroni, 2007). Similarly, 'forced choice' does not adequately reflect the 'voluntary' framing of the desegregation plan that allowed whites to expand their educational options (Holt, 2000; Miner, 2013). As I argued above, the development of the MPCP has actually limited African American community control of schools, although Nelsen grouped the MPCP with other choice-based policies to argue that families in the 'era of school choice' had more options than ever. While I do not wholly disagree with this assessment of educational options, I think it would benefit greatly if coupled with a robust critique of white supremacy.

Indeed, as Nelsen (2015) discussed the contemporary education era, his degree of racial analysis seemed to wane substantially. For example, in describing high school parental activism after a "rash of violence between 2010 and 2012" (p. 171), Nelsen did not mention race:

The Bay View neighborhood, which is noted for its liberal values and commitment to the city and urban life, wanted a neighborhood high school. Parents asked that the current Bay View student body be removed and that the school introduce a rigorous college-preparatory curriculum and an admissions test for non-neighborhood students. Some people have accused Bay View parents of being "elitist," but Bay View parents say they just want what is best for their children (p. 171). 
The historical antecedents and contemporary subtexts of this parental activism remain obscured in Nelsen's account. He did not mention the racial demographics of Bay View — where 80.6\% of residents were white in 2015 (Statistical Atlas, 2015) or connect these parents' demands to prior white activism for neighborhood schools in Milwaukee (Miner, 2013). The parents' calls for a neighborhood school privileging neighborhood residents thus amount to an insistence on white racial favoritism. Tellingly, the 'removal' of current students (of color ${ }^{3}$ ) and the use of admissions exams constitute thinly veiled tools of whiteness' right to exclude (Harris, 1993). These subtexts are not made explicit in Nelsen's account, and he left untroubled the parents' claim to "just want what is best for their children." Instead, he noted that the school board decided to create a new academic program and reduce busing at Bay View High School in 2013. Nelsen then deferred judgement: "Only time will tell if the changes will be effective" (p. 172).

This effectiveness is understood to be academic achievement, measured by standardized test scores. Nelsen (2015) presented standardized test scores as an objective-indeed as the ultimate-measure of school quality. He questioned the marketbased rationale that held parental choice as the key to improving academic quality, especially when many parents "were not successful in school" (p. 177) and were not "well informed" (p. 176). Nelsen claimed that "stable, middle-class families" (p. 177) were more likely to aid their children's success in school, and thus he noted the limits of school choice in affecting these "family-related factors" (p. 177).

Nelsen's account is problematic in at least three fundamental ways. First, he neglected the vast body of research attesting to the wealth of knowledge that students from marginalized communities bring to their formal schooling (e.g. Ball, 1998; González et al., 2005). Second, he did not consider how standardized testing fundamentally reduces complicated phenomena like learning, and in so doing, furthers white supremacy (Harris, 1993; Leonardo, 2009). Lastly, by framing poverty and family in/stability as only "family-related factors," Nelsen offered an atomizing discourse of the social, which obscures broader structures of economic exploitation and their sustenance of white supremacy (Robinson, 2000). Despite its limitations, Educating Milwaukee (Nelsen, 2015) has offered an important perspective to this study. It embodies and reveals some of the contradictions in white liberal discourses about race.

As the six texts attest, the history of school choice in Milwaukee cannot be seriously inscribed without discussing race and racism. However, the three texts that did so uncritically engaged in what I am referring to as race taming, a fragmentary analysis of race, racism, and white supremacy that serves to advance an expedient argument and foreclose deeper social transformation. Here, I draw from Gloria Anzaldúa's (2012) chapter, "How to Tame a Wild Tongue," which describes the violent disciplining of language as a central mechanism in the racialization of U.S. Latinxs. My discussion also owes much to Bonilla-Silva's (2013) description of minimizing racism in colorblind ideology, yet race taming differs since it does not eschew questions of race but rather seeks to make those questions manageable, containable, and safe for white people. In

\footnotetext{
${ }^{3}$ In the 2011-2012 school year, the Bay View High School student population was: $51.9 \%$ Black; $31.1 \%$ Hispanic; $13.3 \%$ White; $1.6 \%$ American Indian; $1.6 \%$ Asian; and $0.6 \%$ two or more races (WISEdash, n.d.).
} 
three of the texts, race taming discourse largely relegated racial analysis to the field of education, tacitly positioned racism as past, and elided class-based dimensions of race, thereby foreclosing the longstanding demands among many Black and Indigenous communities for material reparations and land repatriation (Byrd et al., 2018).

Race taming discourse asserts that policy tweaks can help schooling become an unproblematic and just institution to 'level the playing field.' Further, as suggested above, race taming transcended education sector. Thus, it was deployed to support school vouchers and traditional public schooling. Yet at a time of post-colorblindness in which whiteness asserts itself as just another racial group (Leonardo, 2020), white liberal critiques of school choice and privatization require as much scrutiny as Trumpism's overt practices of public divestment and white racial domination. The danger is that each variant engages in racial analysis while refusing to acknowledge the breadth of the exclusionary mechanisms explicated throughout this research synthesis, advancing instead a favored and insufficient education policy. I continue my discussion of the tenuousness of converging interests in the final section.

\section{Concluding Remarks}

School choice is not a monolithic phenomenon. As the collection of texts in this metaethnography demonstrates, market-based reforms have been taken up in Milwaukee for disparate purposes; at the same time, the white supremacist exclusion structuring de facto segregation continues to operate across school sectors throughout the region. This cross-sector exclusion is an important mechanism to consider, especially since the 2020 MPS referendum diverges from the past three decades' persistent divestment from the public sector and movement toward the universalization of private school vouchers, now available statewide (Pugh, 2017). Crucially, the MPS referendum has not taken place in isolation. Since 2016, voters have approved referenda in close to two-thirds of all public school districts throughout Wisconsin. In the spring 2020 election alone, voters passed 52 out of $60(87 \%)$ referenda, allocating over $\$ 1.7$ billion of additional funding to public school districts (Wisconsin Policy Forum, 2020). This trend can be understood as a popular response to former Wisconsin Governor Scott Walker's agenda to debilitate organized labor specifically, and the public sector more broadly.

Across the US, cognates of Walker's policies, brazenly ramped up under the Trump administration, have coincided with increasing wealth inequality and a pervasive anxiety afflicting both people of color and white people, but in fundamentally different ways (De Lissovoy, 2018). Yet unabashed desires to privatize education, exemplified through the work of former U.S. Education Secretary Betsy DeVos, have been met with massive teacher strikes and a move by many Democrats to distance the official party platform from its formerly robust support of charter schools. Further, the accelerating inequalities and massive financial shifts stemming from the COVID-19 pandemic are bringing into greater relief a series of long-standing crises in education, healthcare, housing, and food security. The global scope of the Black Lives Matter protests after the brutal police murders of George Floyd, Breonna Taylor, and so many others, have unapologetically forced discussions of racial justice 
into popular media. These elements of the contemporary education scene may point to the convergence of multiple interests among different communities of color, as well as some low- and middle-income white communities.

Countless projects have sought to channel converging interests toward educational equity and racial justice. For example, regional equity approaches (Holme \& Finnigan, 2018), in which urban and suburban municipal governments pool resources and flip the individualistic paradigm of market-based competition to instead 'strive together,' offer some potential to enhance the educational experiences of marginalized populations. Processes of gentrification and displacement in urban and suburban areas suggest that cross-municipal collaboration is becoming more politically viable (Holme \& Finnigan, 2018). Yet such approaches may remain susceptible to an overreliance on educational philanthropists and elite power brokers; indeed, elite interests have undermined various progressive initiatives in education, including small schools movements in Milwaukee and Chicago (Lipman, 2011; Rondy, 2011). Similarly, an interest in public education did not preclude white, middle-class families from advocating for choice-based exclusions in New York City public schools after the 2008 economic recession (Aggarwal, 2018). These cases resonate with Bell's (1980) perspicacious warning of the dangers and limitations of interest convergence. Further, contemporary corporate gestures toward racial justice, similar to the race taming discourses described in this study, may reflect superficial adjustments that seek to appropriate and defuse demands for radical social transformation (Love, 2019). Even so, as Bell (1980) argued about the civil rights movements in the US during the 1950s and 60s, it may have become untenable for increasing numbers of whites to deny the existence and implications of the structures of white supremacy endemic to the US.

Because white paternalism undermined the radical possibilities of prior social movements for racial justice, and especially those focusing on Black-White solidarity, De Lissovoy and Brown (2013) suggest an educational approach different from simply forming 'white allies': "the more crucial project, in political-strategic terms, is to develop understandings and relationships among teachers-both teachers of color and White teachers-who have already attained a basic level of critical commitment and antiracist intention" (p. 557). Antiracist solidarity projects that recognize the existential depths and global scope of whiteness and coloniality are better situated to challenge and transform the colonial partitioning of schooling and the world. So how might an antiracist education movement take shape, particularly one that begins with a critical commitment, not unlike the critical perspectives presented in this study? One response would be to prioritize the policy proposals of various youth- and community-led groups of color, ${ }^{4}$ whose voices constitute the greatest potential to guide collective and contingent work, not toward greater inclusion in a multiracial settler state but rather toward its very transformation.

\footnotetext{
${ }^{4}$ In Milwaukee, several groups already engaged in this work include: Leaders Igniting Transformation, Youth Empowered in the Struggle (YES!), and Alianza Latina Aplicando Soluciones (ALAS). A challenge remains transgressing urban-suburban divisions in order to radicalize the potential of regional equity approaches.
} 


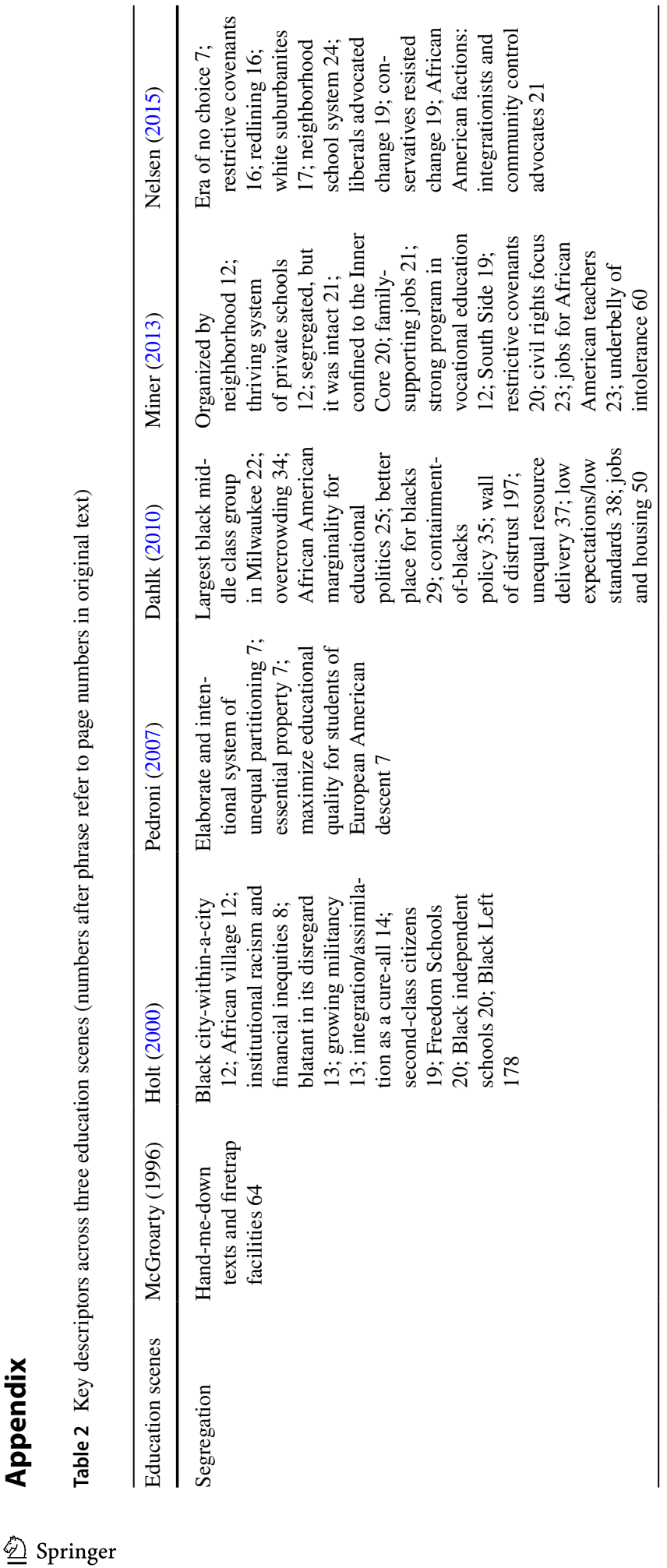




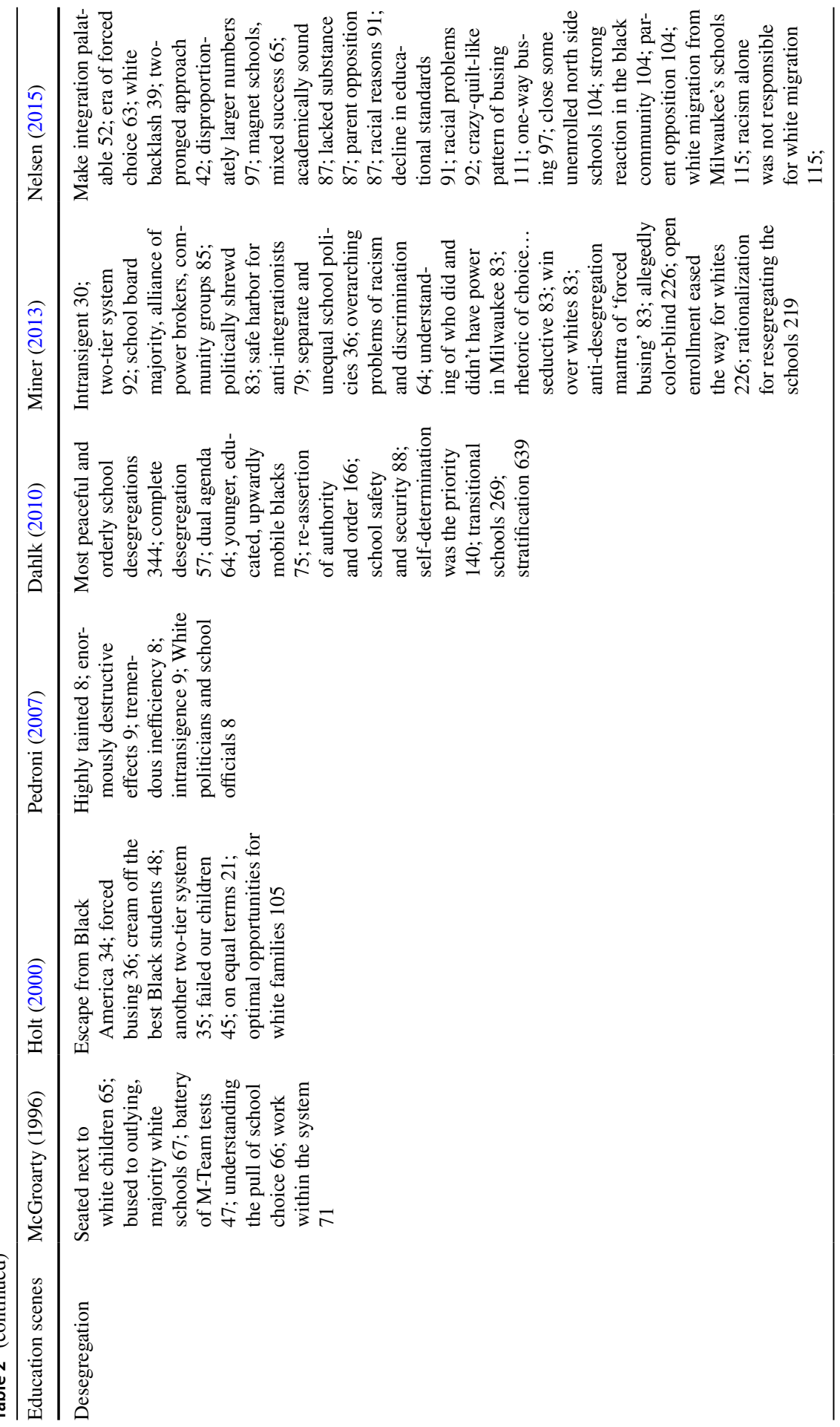




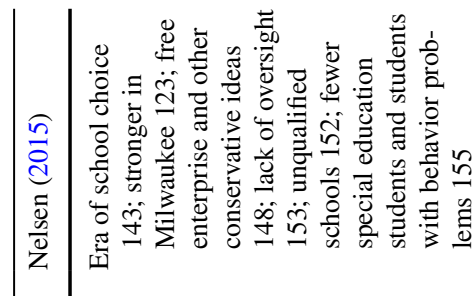

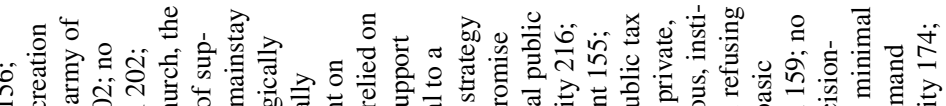

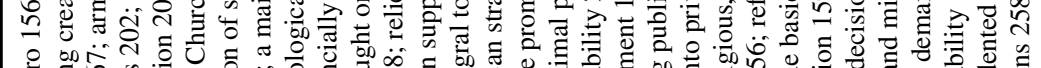

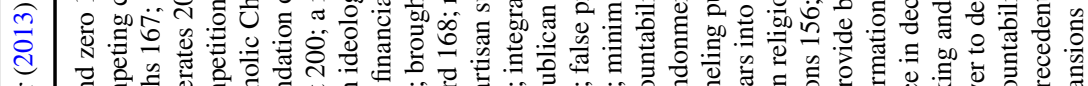

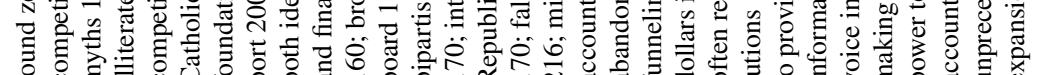

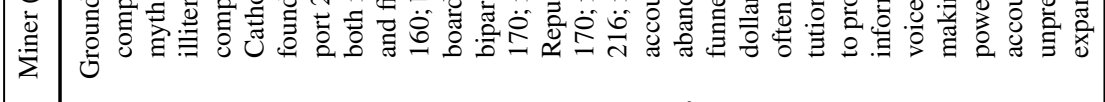

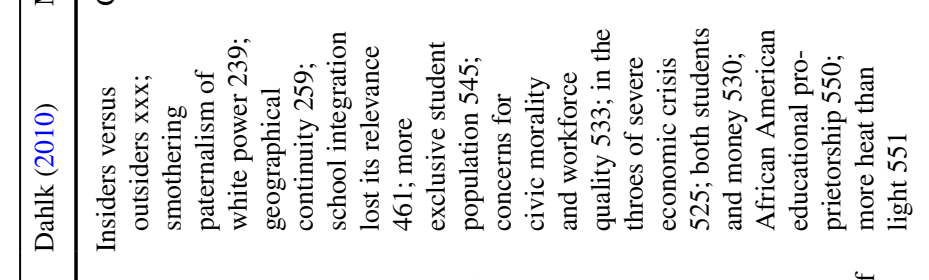

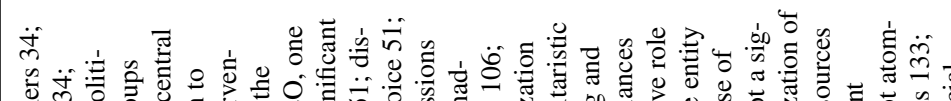

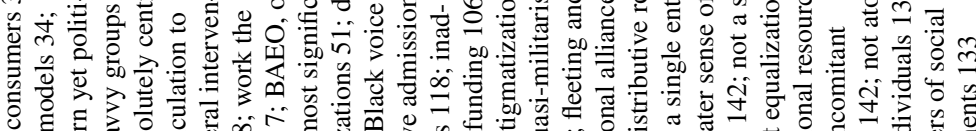

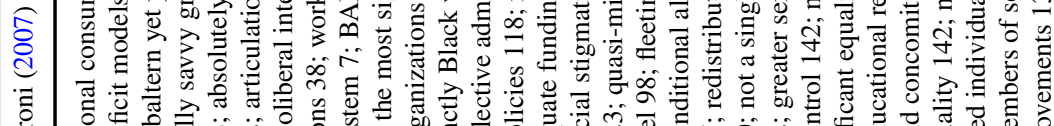

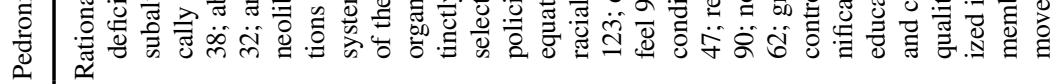

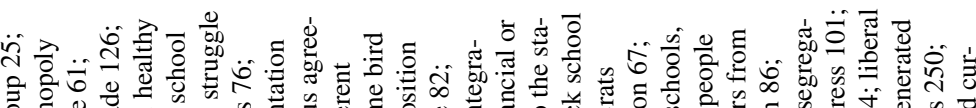

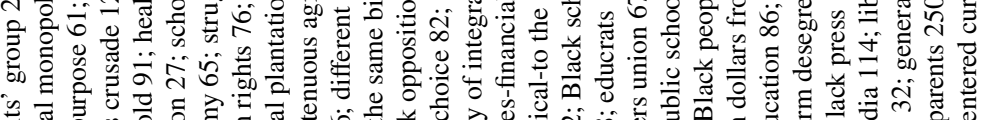

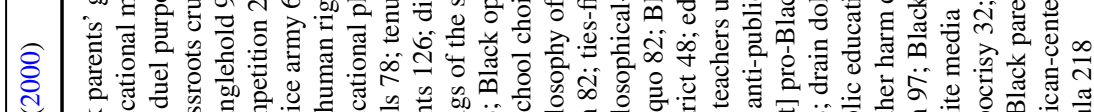
尊

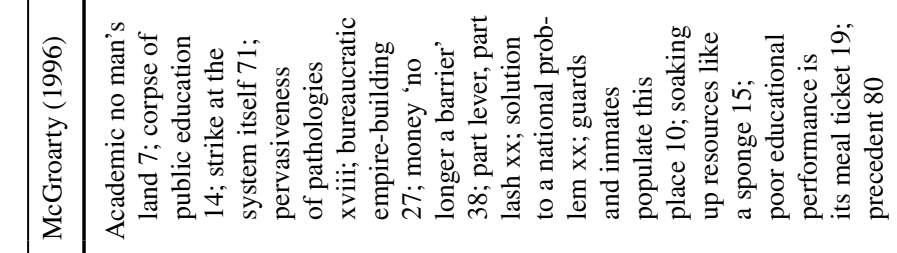

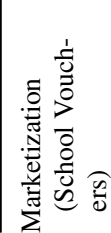




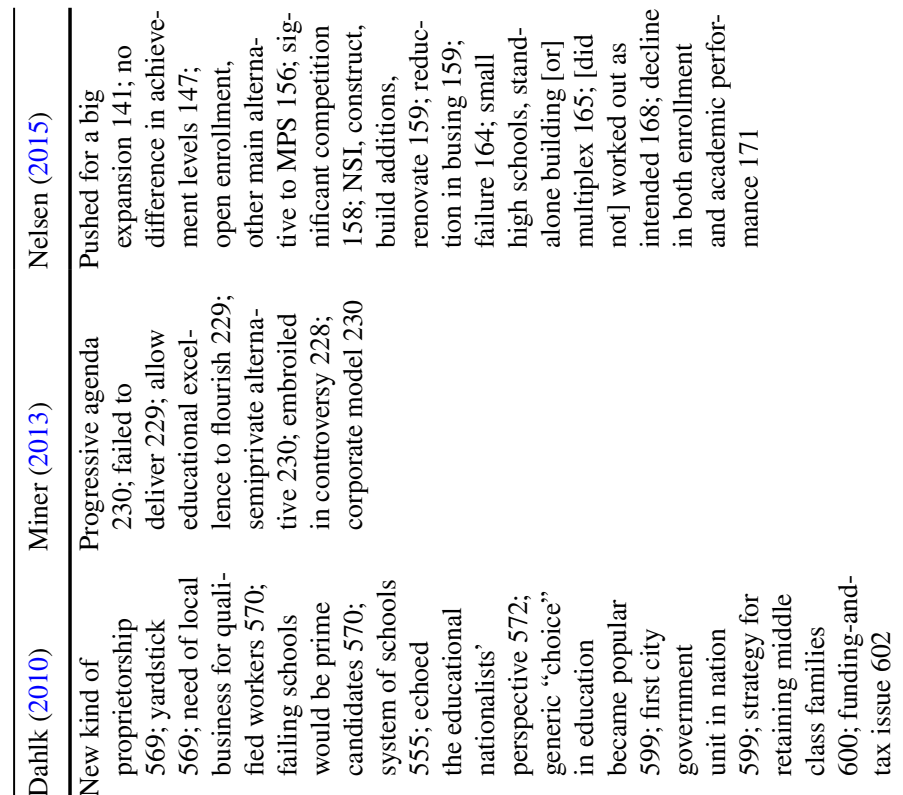


Acknowledgements Andrew wishes to acknowledge the insightful comments on earlier drafts of this manuscript by Luis Urrieta, Jr., Enrique David Degollado, and the anonymous peer reviewers. All errors are his own.

\section{References}

Aggarwal, U. (2016). The ideological architecture of whiteness as property in educational policy. Educational Policy, 30(1), 128-152. https://doi.org/10.1177/0895904815616486.

Aggarwal, U. (2018). After rights: Choice and the structure of citizenship. In L. Fernandes (Ed.), Feminists rethink the neoliberal state: Inequality, exclusion, and change (pp. 71-105). New York University Press.

Anzaldúa, G. (2012). Borderlands/La frontera: The new mestiza (4th ed.). Aunt Lute Books.

Ball, A. F. (1998). Evaluating the writing of culturally and linguistically diverse students: The case of the African American Vernacular English speaker. In C. R. Cooper \& L. Odell (Eds.), Evaluating writing: The role of teachers' knowledge about text, learning, and culture (pp. 225-248). National Council of Teachers of English Press.

Beck, M. (2017). Betsy DeVos tied to millions spent in Wisconsin politics. Wisconsin State Journal. https://madison.com/wsj/news/local/govt-and-politics/betsy-devos-tied-to-millions-spent-in-wisco nsin-politics/article_e05c99b0-4281-593a-b25e-229eb75c1107.html.

Bell, D. A, Jr. (1980). Brown v. Board of Education and the interest-convergence dilemma. Harvard Law Review, 93(3), 518-533.

Bonilla-Silva, E. (2013). Racism without racists: Color-blind racism and the persistence of racial inequality in the United States. Rowman \& Littlefield Publishers.

Brown, A. L., \& De Lissovoy, N. (2011). Economies of racism: Grounding education policy research in the complex dialectic of race, class, and capital. Journal of Education Policy, 26(5), 595-619. https://doi.org/10.1080/02680939.2010.533289.

Byrd, J. A., Goldstein, A., Melamed, J., \& Reddy, C. (2018). Predatory value: Economies of dispossession and disturbed relationalities. Social Text, 36(2(135)), 1-18. https://doi.org/10.1215/01642 472-4362325.

Carl, J. (1996). Unusual allies: Elite and grass-roots origins of parental choice in Milwaukee. Teachers College Record, 98(2), 266-285.

Carmot Strategic Group. (2019). Carmot principal [Webpage]. https://carmotsg.com/who-we-are.

Carnoy, M. (2017). School vouchers are not a proven strategy for improving student achievement. Economic Policy Institute. https://eric.ed.gov/?id=ED579337.

Carnoy, M., Adamson, F., Chudgar, A., Luschei, T. F., \& Witte, J. F. (2007). Vouchers and public school performance: A case study of the Milwaukee Parental Choice Program. Economic Policy Institute.

Chapman, T. K., \& Antrop-González, R. (2011). A critical look at choice options as solutions to Milwaukee's schooling inequities. Teachers College Record, 113(4), 787-810.

Charmaz, K. (2006). Constructing grounded theory: A practical guide through qualitative analysis. Sage.

City of Milwaukee. (2019). Voting ward demographics. City of Milwaukee. https://data.milwaukee.gov/ dataset/voting-ward-demographics/resource/02611877-8885-4742-b4e5-7e930b1f98d4.

City of Milwaukee. (2020). Milwaukee Public Schools Referendum. City of Milwaukee. https://data. milwaukee.gov/dataset/april-7-2020-spring-election/resource/44eecd3b-c7b7-441a-94fb-95094 d03be7d.

Crotty, M. (2012). The foundations of social research: Meaning and perspective in the research process. Sage.

Dahlk, B. (2010). Against the wind: African Americans and the schools in Milwaukee, 1963-2002. Marquette University Press.

De Lissovoy, N. (2018). Pedagogy of the anxious: Rethinking critical pedagogy in the context of neoliberal autonomy and responsibilization. Journal of Education Policy, 33(2), 187-205.

De Lissovoy, N., \& Brown, A. L. (2013). Antiracist solidarity in critical education: Contemporary problems and possibilities. The Urban Review, 45(5), 539-560.

Diaz, R., Rauh, R., \& Tyson, H. (2020). Opinion: There are better fixes for Milwaukee's school funding needs than the MPS referendum. Milwaukee Neighborhood News Service. https://milwaukeenns.org/ 
2020/03/02/opinion-there-are-better-fixes-for-milwaukees-school-funding-needs-than-the-mps-refer endum/.

Dougherty, J. (2004). More than one struggle: The evolution of Black school reform in Milwaukee. University of North Carolina Press. https://doi.org/10.5149/uncp/9780807855249.

Doyle, L. H. (2003). Synthesis through meta-ethnography: paradoxes, enhancements, and possibilities. Qualitative Research, 3(3), 321-344. https://doi.org/10.1177/1468794103033003.

Epstein, R. J. (2020). Upset victory in Wisconsin Supreme Court race gives Democrats a lift. New York Times. https://www.nytimes.com/2020/04/13/us/politics/wisconsin-primary-results.html.

Farrell, W. C., \& Mathews, J. (2006). The Milwaukee school voucher initiative: Impact on black students. The Journal of Negro Education, 75(3), 519-531.

Ford, M. R. (2017). The consequences of governance fragmentation: Milwaukee's school voucher legacy. Lexington Books.

Freire, P. (1971). Pedagogy of the oppressed (M. Bergman Ramos, Trans.). Herder and Herder. (Original work published 1968).

Golann, J. W., \& Torres, A. C. (2018). Do no-excuses disciplinary practices promote success? Journal of Urban Affairs. https://doi.org/10.1080/07352166.2018.1427506.

González, N., Moll, L. C., \& Amanti, C. (Eds.). (2005). Funds of knowledge: Theorizing practices in households, communities, and classrooms. Lawrence Erlbaum.

Harris, C. I. (1993). Whiteness as property. Harvard Law Review, 106(8), 1707-1791. https://doi.org/10. $2307 / 1341787$.

Henig, J. R. (2009). Geo-spatial analyses and school choice research. American Journal of Education, 115(4), 649-657. https://doi.org/10.1086/599784.

Holland, D., \& Lave, J. (Eds.). (2001). History in person: Enduring struggles, contentious practice, intimate identities. SAR Press.

Holme, J. J., \& Finnigan, K. S. (2018). Striving in common: A regional equity framework for urban schools. Harvard Education Press.

Holt, M. (2000). Not yet "free at last": The unfinished business of the civil rights movement: Our battle for school choice. Institute for Contemporary Studies Press.

Irvine, J. J., \& Irvine, R. W. (2007). The impact of the desegregation process on the education of Black students: A retrospective analysis. Journal of Negro Education, 76, 297-305.

Johnson, A. (2016). Urban Day School of Milwaukee to close at end of school year. Milwaukee Journal Sentinel. http://archive.jsonline.com/news/education/urban-day-school-of-milwaukee-to-close-atend-of-school-year-b99702949z1-375073821.html/.

Johnson, A. (2020). Unlike racial split of 1993, data shows $\$ 87$ million MPS referendum passed in all but two Milwaukee wards. Milwaukee Journal Sentinel. https://www.jsonline.com/story/news/polit ics/elections/2020/04/18/election-data-shows-mps-referendum-passed-wide-level-support/51365 98002/.

Jones, P. D. (2009). The Selma of the North: Civil rights insurgency in Milwaukee. Harvard University Press.

Kava, R. (2017). Open enrollment program: Informational paper 26. Wisconsin Legislative Fiscal Bureau. https://docs.legis.wisconsin.gov/misc/lfb/informational_papers/january_2017/0026_open_ enrollment_program_informational_paper_26.pdf.

Kava, R. \& Pugh, C. (2017). State aid to districts: Information paper 24. Wisconsin Legislative Fiscal Bureau. https://docs.legis.wisconsin.gov/misc/lfb/informational_papers/january_2017/0024_state_ aid_to_school_districts_informational_paper_24.pdf.

Lack, B. (2011). Anti-democratic militaristic education: An overview and critical analysis of KIPP schools. Counterpoints, 402, 65-90.

Ladson-Billings, G. (2006). From the achievement gap to the education debt: Understanding achievement in US schools. Educational Researcher, 35(7), 3-12.

Leonardo, Z. (2009). Race, whiteness, and education. Routledge. https://doi.org/10.4324/9780203880 371.

Leonardo, Z. (2013). Race frameworks: A multidimensional theory of racism and education. Teachers College Press.

Leonardo, Z. (2020). The Trump presidency, post-colorblindness and the reconstruction of public race speech. In O. K. Obasogie (Ed.), Trumpism and its discontents (pp. 18-37). Berkeley Public Policy Press.

Lipman, P. (2011). The new political economy of urban education: Neoliberalism, race, and the right to the city. Taylor \& Francis. 
Love, B. L. (2019). We want to do more than survive: Abolitionist teaching and the pursuit of educational freedom. Beacon Press.

Margonis, F., \& Parker, L. (1995). Choice, privatization, and unspoken strategies of containment. Educational Policy, 9(4), 375-403.

Metcalfe, E. (2014). Commanding a movement: The Youth Council Commandos' quest for quality housing. The Wisconsin Magazine of History, 98(2), 2-15.

Miles, M. B., Huberman, A. M., \& Saldaña, J. (2014). Qualitative data analysis: A methods sourcebook (3rd ed). Sage.

Milner, H. R. (2008). Critical race theory and interest convergence as analytic tools in teacher education policies and practices. Journal of Teacher Education, 59(4), 332-346.

Miner, B. (2013). Lessons from the heartland: A turbulent half-century of public education in an iconic American city. The New Press.

Nelsen, J. K. (2015). Educating Milwaukee: How one city's history of segregation and struggle shaped its schools. Wisconsin Historical Society Press.

Noblit, G. W. (2018). Meta-ethnography: Adaptation and return. In L. Urrieta Jr. \& G. W. Noblit (Eds.), Cultural Constructions of Identity: Meta-ethnography and Theory (pp. 34-50). Oxford University Press. https://doi.org/10.1093/oso/9780190676087.003.0002.

Noblit, G. W., \& Hare, R. D. (1988). Meta-ethnography: Synthesizing qualitative studies. Sage Publications. https://doi.org/10.4135/9781412985000.

Pedroni, T. C. (2007). Market movements: African American involvement in school voucher reform. Routledge.

Pugh, C. (2017). Private school choice programs: Informational paper 25. Wisconsin Legislative Fiscal Bureau. https://docs.legis.wisconsin.gov/misc/lfb/informational_papers/january_2017/0025_priva te_school_choice_programs_informational_paper_25.pdf.

Richards, E. (2010). Stricter voucher program regulations claim next victim: Harambee School. Milwaukee Journal Sentinel. http://archive.jsonline.com/blogs/news/83489822.html.

Richards, E. (2011). Harambee Community School remains shuttered. Milwaukee Journal Sentinel. http://archive.jsonline.com/news/education/113541999.html/.

Robinson, C. J. (2000). Black Marxism: The making of the Black radical tradition. University of North Carolina Press.

Rondy, J. (2011). The human cost. Milwaukee Magazine. https://www.milwaukeemag.com/TheHumanCo st/.

Statistical Atlas. (2015). Race and ethnicity in Bay View, Milwaukee, Wisconsin (neighborhood). https:// statisticalatlas.com/neighborhood/Wisconsin/Milwaukee/Bay-View/Race-and-Ethnicity.

Sung, K. K. (2018). Raciolinguistic ideology of antiblackness: Bilingual education, tracking, and the multiracial imaginary in urban schools. International Journal of Qualitative Studies in Education, 31(8), 667-683.

Trotter, J. W. (2007). Black Milwaukee: The making of an industrial proletariat, 1915-45. University of Illinois Press.

Tuck, E., \& McKenzie, M. (2015). Place in research: Theory, methodology, and methods. Routledge.

Tyack, D. B. (1974). The one best system: A history of American urban education. Harvard University Press.

Urrieta, L, Jr., Noblit, G. W., \& (Eds.)., (2018). Cultural constructions of identity: Meta ethnography and theory. Oxford University Press. https://doi.org/10.1093/oso/9780190676087.001.0001.

Van Dunk, E., \& Dickman, A. M. (2003). School choice and the question of accountability: The Milwaukee experience. Yale University Press. https://doi.org/10.12987/yale/9780300099423.001.0001.

Verger, A., Fontdevila, C., \& Zancajo, A. (2016). The privatization of education: A political economy of global education reform. Teachers College Press.

Wisconsin Historical Society. (2020). Black history in Wisconsin. https://www.wisconsinhistory.org/ Records/Article/CS502.

Wisconsin Information System for Education Data Dashboard (WISEdash). (n.d.). Enrollment percent by race/ethnicity (2010-2011). http://wisedash.dpi.wi.gov/Dashboard/portalHome.jsp.

Wisconsin Policy Forum. (2020). Amid crisis, voters again support more money for schools. Wisconsin Policy Forum. https://wispolicyforum.org/wp-content/uploads/2020/04/Focus_20_09_School_Refer enda.pdf.

Witte, J. F. (2000). The market approach to education: An analysis of America's first voucher program. Princeton University Press. 
Witte, J. F., Wolf, P. J., Cowen, J. M., Carlson, D. E., \& Fleming, D. J. (2014). High-stakes choice: Achievement and accountability in the nation's oldest urban voucher program. Educational Evaluation and Policy Analysis, 36(4), 437-456. https://doi.org/10.3102/0162373714534521.

Wolf, P. J. (2012). The comprehensive longitudinal evaluation of the Milwaukee Parental Choice Program: Summary of final reports, Report \#36. Fayetteville, AR: School Choice Demonstration Project, University of Arkansas. http://www.uaedreform.org/downloads/2012/02/report-36-the-compr ehensive-longitudinal-evaluation-of-the-milwaukee-parental-choice-program.pdf.

Publisher's Note Springer Nature remains neutral with regard to jurisdictional claims in published maps and institutional affiliations. 